\title{
INDEKS SUBJEK
}

akselerasi, 47, 48, 49, 50, 51, 52, 53, 54, 55, 56, 57, 58, 59, 60, 61, 62

benefit, $77,83,84,86$

Buku Sekolah Elektronik, 33, 34, 35, 45

cost ratio, 77,83

evaluasi, 4, 5, 6, 12, 15, 20, 23, 24, 25, 26, 28, 29, 30, 33, 35, 49, 52, 63, 65, 66, 68, 69, 76, $83,90,93,114,116,122,125,127,129,136,137,138,140$

guru pendidikan khusus, 88, 89, 92, 93, 94, 95, 96, 97, 99

human capital investment, 77, 81, 82, 83

implementasi, 1, 3, 9, 17, 19, 21, 26, 27, 28, 29, 30, 32, 33, 35, 36, 41, 44, 47, 49, 50, 56, 60, $62,63,66,69,133$

implementasi SPMI, 17, 20, 26, 30, 31

internal rate of return, 77,83

keefektifan, 63, 114, 116, 118, 129

kepala sekolah, 1, 2, 3, 4, 5, 6, 7, 8, 9, 10, 11, 13, 14, 15, 16, 34, 41, 47, 49, 50, 52, 53, 54, 55, $56,58,59,60,61,65,69,74,75,104,109,110,111,112,114,115,116,126,127,129$, $131,132,133,135,136,137,138,139,140,141,143,144$

kepuasan, 18, 19, 20, 21, 30, 98, 101, 102, 103, 105, 106, 107, 108, 109, 110, 111, 112

kesejahteraan, 101, 102, 104, 105, 106, 107, 108, 109, 110, 111, 112, 133

komitmen kerja guru, 101, 102, 105, 106, 107, 108, 109, 110, 111, 112

kompetensi manajerial, 1, 4, 8, 9, 15, 16, 134

manajemen, 2, 3, 4, 6, 7, 12, 17, 21, 22, 23, 24, 25, 28, 30, 31, 33, 35, 36, 41, 44, 45, 56, 62, $63,66,69,70,76,78,81,95,98,99,102$

mutu pendidikan, $7,17,18,19,20,21,23,24,25,26,27,29,30,31,34,110,115,116,127$, 129

net present value, 77,83

payback period, $77,83,84,86$

pemberdayaan perpustakaan sekolah, 131, 138, 141

pendidikan inklusif, 63, 64, 65, 66, 69, 74, 75, 76

pengalaman, $1,3,4,5,7,15,56,81,90,101,102,103,104,105,106,107,108,109,110$, $111,112,119,120,141,143$

penjaminan mutu, 17, 18, 19, 20, 23, 24, 25, 26, 27, 28, 29, 30, 31, 32, 114, 115, 116, 128, 129

peran kepala sekolah, 131, 133, 135

peran pustakawan, 131, 141

profesionalisme guru, 88, 90, 91, 92, 95, 97, 99, 100, 112

program, 1, 4, 5, 6, 10, 12, 13, 15, 16, 19, 21, 23, 24, 25, 27, 28, 29, 30, 31, 33, 34, 35, 36, 41, $43,44,45,46,47,48,49,50,51,52,54,56,58,60,61,62,64,66,68,70,74,76,86,89$, $90,91,92,100,104,105,106,115,126,132,134,135,136,137,138,139,140,141,142$, 143

return on investment, 77,83

standar proses, 67, 70, 72, 114, 115, 116, 127, 128, 129 
INDEKS PENGARANG

Adi, 1

Ahmad Sulaiman, 17

Aris Suharyadi, 33

Basuki, 47, 56

Cepi Safruddin Abdul Jabar, 33

Dian Putera Karana, 63

Fitri Nur Mahmudah, 77

Ida Ayu Dian Pramantik, 88

Lantip Diat Prasojo, 77

Louwis Jarfi, 101

Muhyadi, 114

Pardjono, 88

Patna Sustiwi, 114

Udik Budi Wibowo, 17

Widya Setyaningrum Bagyoastuti, 131

Wiwik Wijayanti, 131 


\title{
BIODATA PENULIS
}

\section{Adi}

Bekerja di Dinas Pendidikan Pelalawan Riau.

\begin{abstract}
Ahmad Sulaiman
Lahir di Bantul tanggal 22 Juni 1975. Pendidikan Sarjana (S1) diselesaikan di Program Studi Pendidikan Administrasi Perkantoran FIS UNY tahun 1999. Pada tahun 2014 menyelesaikan S2 di Program Studi Manajemen Pendidikan Program Pascasarjana UNY. Saat ini bekerja sebagai Kepala Seksi Kelembagaan pada Direktorat Akademik Universitas Gadjah Mada.
\end{abstract}

\section{Aris Suharyadi}

Lahir di Palembang 13 April 1989. Tahun 2007 menempuh pendidikan S-1 di Program Studi Manajemen Pendidikan, Fakultas Ilmu Pendidikan, UNY dan lulus pada tahun 2012. Pada tahun 2013 melanjutkan ke jenjang S-2 di Program Studi Manajemen Pendidikan, Program Pascasarjana, UNY dan lulus pada tahun 2015.

\section{Basuki}

Dilahirkan di Bantul, 14 Desember 1969. Pendidikan D2 PGSD guru kelas ditempuh di IKIP Negeri Surabaya tahun 1992. Sarjana ditempuh di STKIP PGRI Bangkalan tahun 2002. Pekerjaan sebagai guru kelas di SD Bantul Timur Kabupaten Bantul sampai sekarang.

\section{Cepi Safruddin Abdul Jabar}

Lahir pada tanggal 31 Agustus 1974. Mendapatkan gelar Sarjana dari Program Studi Administrasi Pendidikan, IKIP Bandung pada tahun 1997. Mendapatkan gelar S-2 dari Program Studi Administrasi Pendidikan, UPI Bandung pada tahun 2005. Selanjutnya menempuh pendidikan S-3 di Program Studi Administrasi Pendidikan, UPI Bandung dan lulus pada tahun 2011. Bekerja sebagai staf pengajar di Universitas Negeri Yogyakarta.

\section{Dian Putera Karana}

Lahir di Yogyakarta pada tanggal 10 Juli 1981. Pendidikan S-1 di Jurusan Administrasi Pendidikan Fakultas Ilmu Pendidikan Universitas Negeri Yogyakarta pada tahun 2000 dan lulus tahun 2004, lalu melanjutkan studi S-2 di Program Studi Manajemen Pendidikan Program Pascasarjana Universitas Negeri Yogyakarta pada tahun 2010. Bekerjadi Dinas Pendidikan Kabupaten Kulon Progo hingga sekarang di Bidang Pendidikan Sekolah Dasar.

\section{Fitri Nur Mahmudah}

Lahir di Sleman pada tanggal 20 Maret 1990. Alamat: Watuadeg RT.02/RW.10, Jogotirto, Berbah, Sleman, Yogyakarta. Perguruan Tinggi : Universitas Negeri Yogyakarta

\section{Ida Ayu Dian Pramantik}

Lahir di Ampelgading, Kabupaten Pemalang, Jawa Tengah pada 20 September 1986. Pendidikan sarjana (S1) ditempuh di Universitan Negeri Yogyakarta, Fakultas Ilmu Pendidikan, Program Studi Pendidikan Luar Biasa. Jurusan Pendidikan Luar Biasa dengan. Selain berkuliah penulis juga aktif dikegiatan non akademik yaitu korp suka rela (KSR) pada tahun 2007. Pada saat ini penulis telah mengajar di SLB Negeri 1 Bantul.

\section{Lantip Diat Prasojo}

Lahir pada tanggal 25 April 1974. Bekerja sebagai staf pengajar di Fakultas Ilmu Pendidikan Universitas Negeri Yogyakarta. Menempuh pendidikan SarjanaTeknik Elektro di Universitas Gadjah Mada, lulus pada tahun 2001. Pada tahun 2005 berhasil menyelesaikan program 
Magister pada Program Studi Manajemen Pendidikan di Program Pascasarjana Universitas Negeri Yogyakarta.

\section{Louwis Jarfi}

Lahir di Sorong, pada tanggal 12 Desember 1970. Tahun 1997 lulus program S1 pada Program Pendidikan Bahasa Inggris, Fakultas Keguruan dan Ilmu Pendidikan Universitas Negeri Cenderawasih Papua dan pada tahun 2014 telah menyelesaikan S2 di Program Studi Manajemen Pendidikan Program Pascasarjana Universitas Negeri Yogyakarta. Saat ini bekerja sebagai guru di SMA Negeri 2 Manokwari Provinsi Papua Barat.

\section{Muhyadi}

Lahir di Klaten pada tanggal 30 Januari 1953. Bekerja sebagai staf pengajar di Fakultas Ekonomi dan Program Pascasarjana Universitas Negeri Yogyakarta. Pada tahun 1987 berhasil menyelesaikan pendidikan S1 Ilmu Adminstrasi di IKIP Yogyakarta. Menyelesaikan Program Magister dan Doktor di IKIP Jakarta.

\section{Pardjono}

Bekerja sebagai staf pengajar di Jurusan Pendidikan Teknik Mesin Fakultas Teknik Universitas Negeri Yogyakarta. Menyelesaikan pendidikan Sarjana Pendidikan Teknik Mesin di IKIP Yogykarata tahun 1977. Pada tahun 1986 menyelesaikan pendidikan Magister pada Industrial Arts and Technology Education di State University of New York. Pendidikan Doktor ditempuh di Deakin University pada Cognitive Education tahun 2000.

\section{Patna Sustiwi}

Lahir pada tanggal 26 Desember 1975 di Sleman. Pendidikan perguruan tinggi S-1 ditempuh pada bidang Administrasi Pendidikan Universitas Negeri Yogyakarta. S-2 ditempuh di Program Pascasarjana Universitas Negeri Yogyakarta. Bekerja sebagai staf pengajar di SD Negeri Percobaan 3 Yogyakarta.

\section{Udik Budi Wibowo}

Dosen Jurusan Administrasi Pendidikan FIP UNY. Pendidikan sarjana Ilmu Administrasi Negara di FISIPOL Universitas Gadjah Mada tahun 1986. Pendidikan magister Administrasi Pendidikan di IKIP Bandung (sekarang Universitas Pendidikan Indonesia) tahun 1993 dan pendidikan doktor Administrasi Pendidikan di Universitas Pendidikan Indonesia tahun 2010.

\section{Widya Setyoningrum Bagyoastuti}

Lahir di Jakarta, 27 Januari 1984. Jenjang S-1 selesai ditempuh pada tahun 2007 di Universitas Gadjah Mada kemudian menyelesaikan jenjang S-2 pada tahun 2013 di Universitas Negeri Yogyakarta program studi Manajemen Pendidikan. Penulis mengawali panggilan dalam dunia pendidikan pada tahun 2008 sebagai salah satu tenaga pengajar di Sekolah Pilar Indonesia hingga tahun 2012. Dengan latar belakang pengalaman sebagai teacher-librarian (guru pustakawan), penulis memperdalam bidang pendidikan dan kepustakaan dengan memberikan pendampingan belajar, menjadi volunteer di salah satu rumah baca, aktif dalam diskusi kependidikan dan menerjemahkan buku.

\section{Wiwik Wijayanti}

Dilahirkan di Sleman tahun 1971 memperoleh gelar Sarjana Jurusan Administrasi Pendidikan di IKIP Yogyakarta tahun 1995, gelar Magister Pendidikan dari UNY tahun 2006 dan gelar Doktor dalam Manajemen Pendidikan di UM tahun 2011. Pekerjaan staf pengajar Fakultas Ilmu Pendidikan Universitas Negeri Yogyakarta. 


\section{PETUNJUK PENULISAN ARTIKEL JURNAL AKUNTABILITAS MANAJEMAN PENDIDIKAN}

1. Panjang artikel journal maksimal 4000 kata atau kurang lebih 15 halaman diketik satu spasi, pada kertas kwarto A4 dengan format 2 kolom, font Times Book Antiqua (BA) 11.

2. Judul dalam bahasa Indonesia, ditulis dengan huruf BA - 11 bold, maksimal 14 kata, rata tengah. Untuk judul versi bahasa Inggris ditulis dengan huruf TBA - 11 bold, maksimal 10 kata, rata tengah.

3. Nama penulis diikuti lembaga afiliasi atau instansi, ditulis dengan huruf kecil (lowercase) BA-11 disertai alamat korespondensi (khususnya email).

4. Abstrak dibuat dari keseluruhan artikel, ditulis paling banyak 3 paragraf dalam dua bahasa (bahasa Indonesia dan Bahasa Inggris). Panjang Abstrak tidak lebih dari 150 kata atau maksimal 1 halaman diketik 1 spasi BA-11. ditulis naratif memuat tujuan, metode serta hasil penelitian.

5. Kata kunci: satu atau lebih kata atau frase yang penting, spesifik, atau representatif bagi artikel ini.

6. Artikel ditulis dalam bahasa Indonesia baku, memuat: (1) Judul, (2) Abstrak, (3) Pendahuluan, (4) Metode Penelitian, (5) Hasil Penelitian dan Pembahasan, (6) Simpulan dan Saran, (7) Daftar Pustaka, dan (8) Biodata Penulis

7. Daftar Pustaka ditulis dengan meratifikasi APA Edisi IV. Ditulis dalam spasi tunggal atau at least 12pt, antardaftar pustaka diberi jarak satu spasi. Sebagian contoh cara penulisan referensi/acuan di dalam DAFTAR PUSTAKA, diberikan berikut.

a. Contoh jika berasal dari buku teks:

Gronlund, N.E. \& Linn, R.L. (1990). Measurement and evaluation in teaching. (6 ${ }^{\text {thed.). }}$. New York: Macmillan.

b. Dari buku teks yang dirangkum oleh editor.

Sofian Effendi. (1982). Unsur-unsur penelitian ilmiah. Dalam Masri Singarimbun (Ed.). Metode penelitian survei. Jakarta: LP3ES.

c. Dari buku terjemahan

Daniel, W.W. (1980). Statistika nonparametrik terapan. (Terjemahan Tri Kuntjoro). Jakarta : Gramedia.

d. Dari skripsi/tesis/desertasi

Slamet Suyanto (2009). Keberhasilan sekolah dalam ujian nasional ditinjau dari organisasi belajar. Disertasi, tidak dipublikasikan. Universitas Negeri Jakarta.

e. Dari jurnal:

Pritchard, P.E. (1992). Studies on the bread-improving mechanism of fungal alphaamylase. Journal of Biological Education,26 (1), 14-17.

\section{f. Dari kumpulan abstrak penelitian atau proceeding:}

Paidi. (2008). Urgensi pengembangan kemampuan pemecahan masalah dan metakog-nitif siswa SMA melalui pembelajaran biologi. Prosiding, Seminar dan Musyawarah Nasional MIPA yang diselenggarakan oleh FMIPA UNY, tanggal 30 Mei 2008. Yogyakarta: Universitas Negeri Yogyakarta.

\section{g. Dari internet}

White, H. (2007). Problem-based learning in introductory science across disciplines. Diakses tanggal 27 Maret 2007 dari http://www.udel.edu/chem/white/finalrpt.html

8. Artikel dikirim ke Redaksi Pengelola Jurnal Gedung Baru 3.20 PPs UNY beserta soft file. Soft file dikirim via email Jurnal PPs UNY journal.pps@uny.ac.id atau (jurnalppsuny@yahoo.com)

9. Selengkapnya mengenai format, (termasuk jumlah kolom, margins, dan font) diatur seperti template yang ada, yang dapat diunduh dari Web PPs UNY (http://pps.uny.ac.id) 